\title{
Management of the Agenesia of the Maxillary Lateral Incisives about 2
}

\section{Cases}

Coulibaly $\mathrm{B}^{1^{*}}$, Touré $\mathrm{K}^{1}$, Kamissoko $\mathrm{K}^{2}$, Traoré $\mathrm{H}^{1}$, $\mathrm{Ba} \mathrm{B}^{1}$, Ba $\mathrm{A}^{1}$, Niang $\mathrm{A}^{1}$, Gueye $\mathrm{S}^{1}$, Diawara $\mathrm{O}^{1}$, Traoré $\mathrm{L}^{1}$, Ba $\mathrm{M}^{1}$, Diallo $\mathrm{B}^{1}$, Sangaré BLC ${ }^{1}$, Touré $\mathrm{A}^{1}$, Sissoko $\mathrm{S}^{1}$, Sissoko $\mathrm{Y}^{1}$, Kané AST

${ }^{1}$ Bamako University Hospital Center for Odontology

${ }^{2}$ Department of dentistry of the armies of Mali

DOI: $10.36347 /$ sjmcr.2020.v08i05.004

| Received: 27.04.2020 | Accepted: 04.05.2020 | Published: 10.05.2020

*Corresponding author: Dr. Bougadary Coulibaly

\section{Abstract}

Agenesis is a disorder frequently encountered in dentistry. It is a congenital absence of the germ from a dental unit. The end of series teeth are the most affected. The lateral incises are the second most affected dental units after the 3 rd molars. It has a direct impact on the aesthetic aspect of the smile, which makes it one of the reasons very often encountered in cosmetic dentistry. Different therapeutic possibilities calling on multidisciplinary skills are possible: the implant prosthesis, conventional bridge, bonded bridge, removable prosthesis, orthodontic closure and finally abstention. We present two clinical cases which have been collected in our department and a review of the literature.

Keywords: Agenesis; lateral incisor, smile aesthetic.

Copyright @ 2020: This is an open-access article distributed under the terms of the Creative Commons Attribution license which permits unrestricted use, distribution, and reproduction in any medium for non-commercial use (NonCommercial, or CC-BY-NC) provided the original author and source are credited.

\section{INTRODUCTION}

The congenital absence of permanent teeth is a relatively common problem in the dental office. Dental agenesis which means etymologically "absence of germ", thus indicates the absence of dental follicle $[1,2]$. It most often affects so-called "end of line" teeth. The prevalence is between $2 \%$ to $10 \%$ of the population and it is the 3rd molar that is most often missing, followed by the maxillary lateral incisors and the 2nd mandibular premolars depending on the population surveyed (put reference to prevalence). Agenesis can affect both the teeth as well as all the teeth of the two arches, with a high frequency at the level of the permanent teeth [3-5]. In the maxilla, the lateral incisors and the second premolars are therefore the teeth most affected [6]. The maxillary lateral incisors, given their strategic position in the smile, can create a major aesthetic problem in the event of absence. Agenesis can have certain consequences with a more or less serious impact depending on the case. Indeed, the absence of a single tooth can alter the organization and functioning of the facial complex and thus have consequences on alveolar and skeletal growth. In addition to the cosmetic deficit, dental agenesis can have repercussions on other oral functions such as phonation and chewing.

The evolution of techniques in dentistry and the complexity of multidisciplinary treatments, make it possible to extend the indications and the therapeutic proposals in patients with agenesis. Different therapeutic possibilities are possible, among which we can cite: the implant prosthesis, conventional bridge, bonded bridge, removable prosthesis, orthodontic closure and finally abstention.

We report two (02) cases of lateral incisor agenesis, which were managed in the prosthesis department at the CHU of odontostomatology in Bamako.

\section{Clinical Case 1}

The 32-year-old MC patient presented for consultation at the joint prosthesis department of the CHU-CNOS in Bamako for an aesthetic problem. The reason for the patient's consultation is essentially aesthetic: the filling of a large diastema between 11 and 21 by prosthetic restoration. The history does not indicate any previous history of treatment. On clinical examination, there was an absence of the upper lateral incisors and a large diastema between teeth 11 and 21 . The panoramic X-ray confirmed the diagnosis in favor of agenesis of the two upper lateral incisors with the absence of the respective dental germs. The treatment plan adopted is an ortho-prosthetic treatment which will consist of: 
- Creation of space for teeth 12 and 22 missing by multi-ring technique in orthodontics

- Creation of a ceramic-metallic bridge with 04 elements.

The patient was referred to the orthodontic department for pre-prosthetic treatment. After 12 months of orthodontic treatment in multi-ring technique, we obtained the spaces necessary for the realization of the prosthesis. Prosthetic therapy was carried out in two stages: the realization of the provisional prosthesis to maintain the orthodontic result, stimulate the neuromuscular and physiological functions followed by the realization of the final prosthesis. We opted for a cantilever type bridge to preserve the integrity of the canines. At the patient's request an inter-incisor diastema was left between teeth 11 and 21.

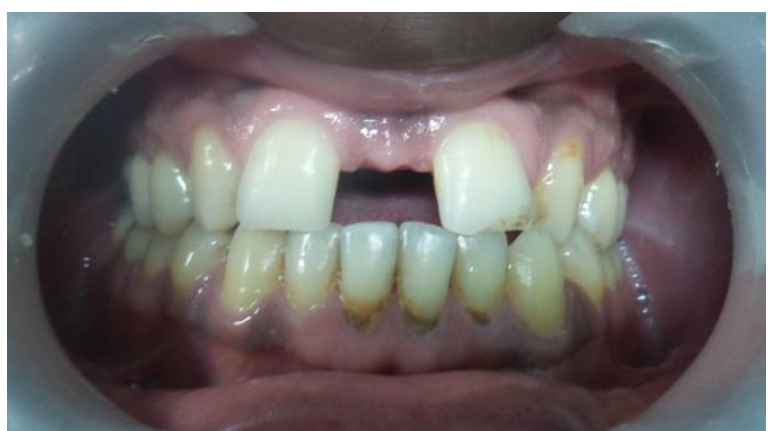

Fig-1: Intraoral view of the front before treatment

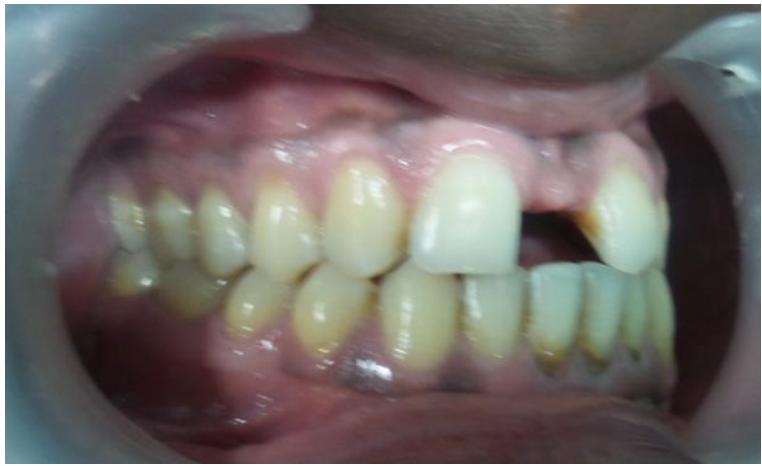

Fig-2: View before treatment

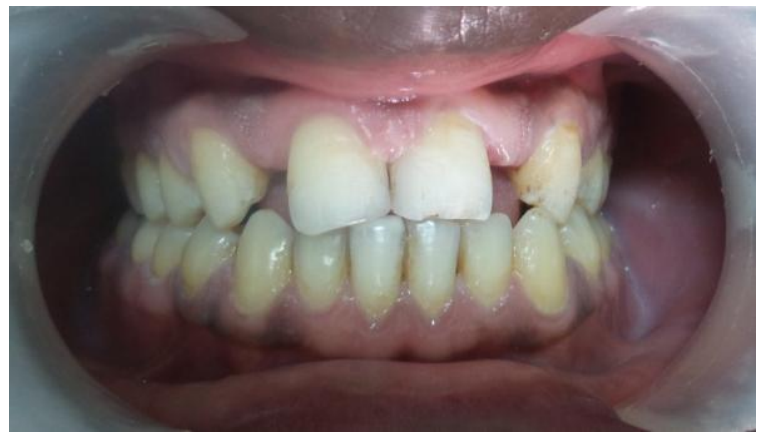

Fig-3: After Orthodontic treatment

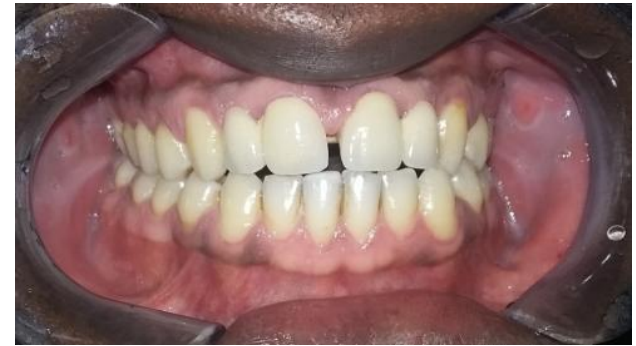

Fig-4: View after prosthetic treatment

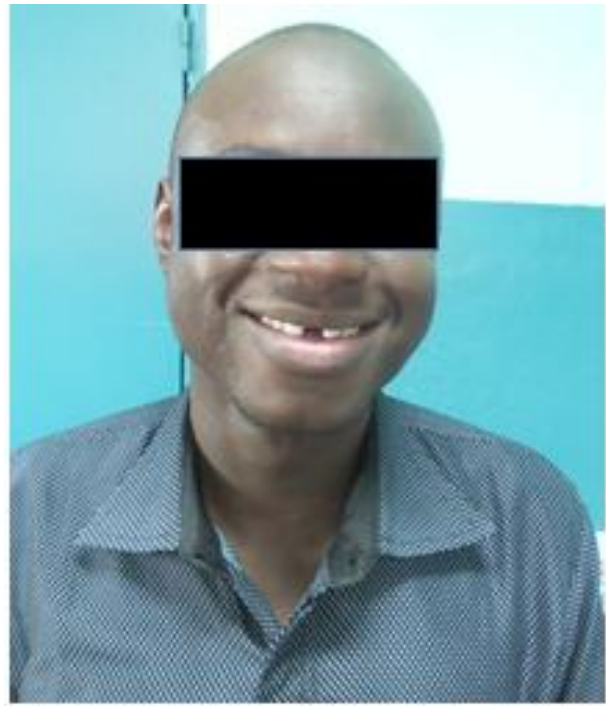

Fig-5: The smile before treatment

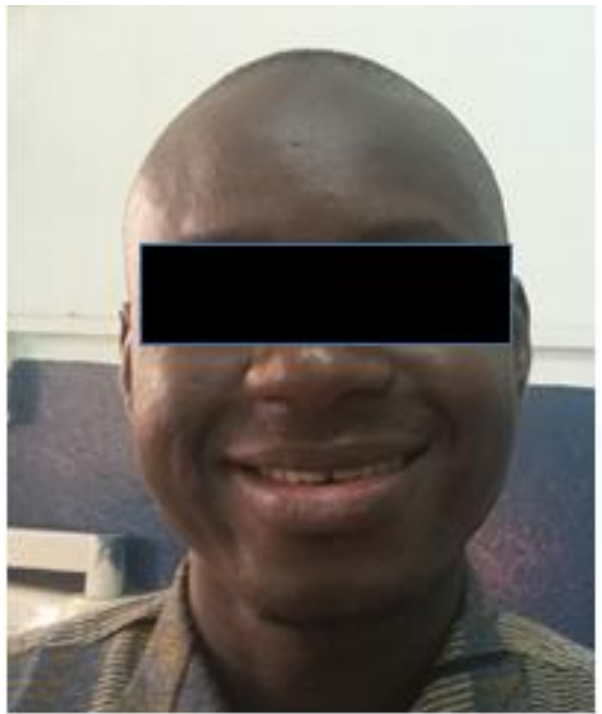

Fig-6: The smile after treatment

\section{Clinical Case 2}

Miss AK, 27, presents for a prosthesis consultation, for an aesthetic reason: a large diastema between the two upper central incisors 11 and 21 and wishes to close this space. The examination revealed no dental or medical-surgical history. The endo-oral examination reveals a large diastema between the 11 and the 21 with the absence of the lateral incisors. The panoramic X-ray confirms the agenesis of 12 and 22 . The proposed orthodontic treatment was abandoned at 
the request of the patient. The prosthetic solution which consisted in making a ceramic-metallic bridge. of 4 elements was retained. At the end of the treatment the patient was satisfied with the result obtained.

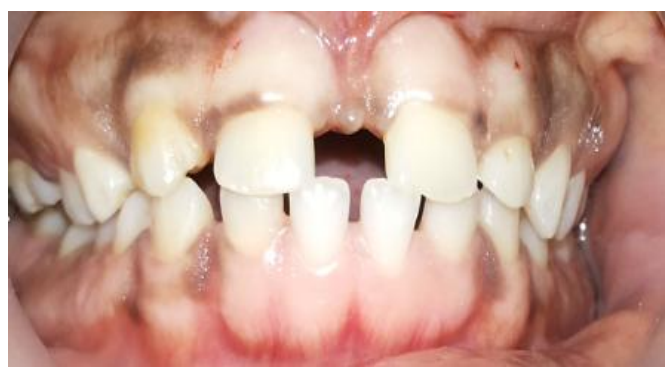

Fig-7: Before treatment

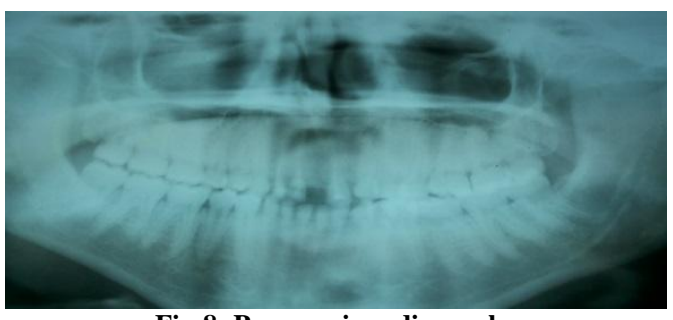

Fig-8: Panoramic radiography

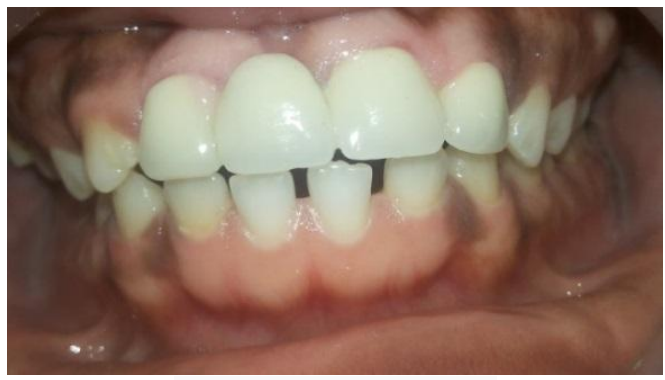

Fig-9: Sealing of the bridge

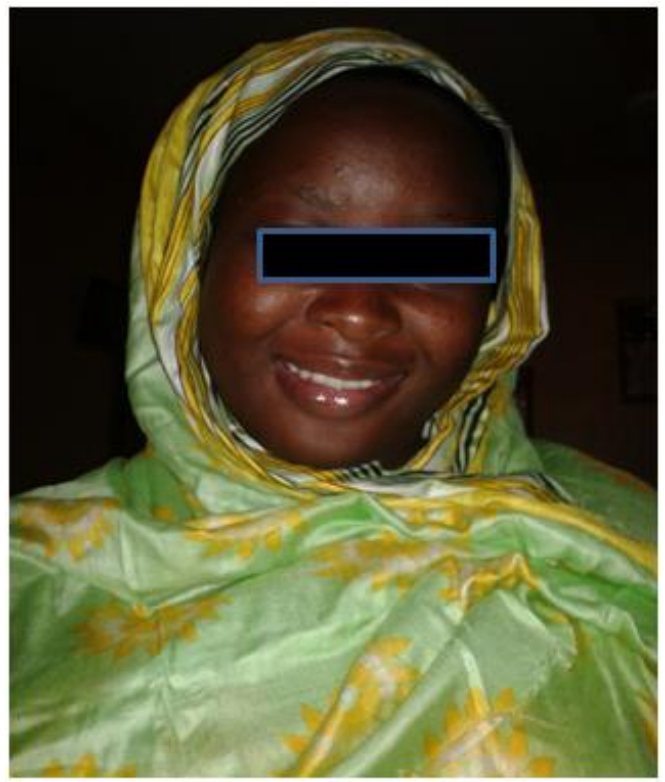

Fig-10: With a smile

\section{DISCUSSION}

Agenesis is a condition very frequently encountered among genetic disorders at the dental level. Without particularity in some people, it can pose a real aesthetic problem pushing patients to consult. The two clinical cases reported have shown that the management of this anomaly is most often multidisciplinary. Therapeutic approaches vary depending on the clinical situation, cooperation and the patient's financial means. $\mathrm{H}$ Chicken and collaborators in their study on an orthodontic population of 1095 patients found $9 \%$ of subjects with at least one agenesis, $3 \%$ of which concerned a lateral incisor [9]. Aesthetics are generally the most common reason for patients consulting for dental agenesis. In our 2 patients, the reason for consultation was identical, namely aesthetic. According to a study by M. Thierry and collaborators, agenesis is multifactorial (the genetic factor being the most implicated), it has a prevalence which would be $5.5 \%$ in Europe and $3.9 \%$ in the United States (teeth wisdom excluded). [7]. Agenesis of the maxillary lateral incisor represents a good part of dental agenesis and very often poses a problem as regards the therapeutic decision [8].

The therapeutic approach requires a perfect collaboration of the patient taking into account the duration of the treatment, often long. We had obtained the informed consent of the 2 patients who were cooperative after having had all the elements of informed edification in relation to management. Multidisciplinary collaboration is essential for better patient care [10]. According to Michel Martin, faced with a patient with agenesis of maxillary lateral incisors, the orthodontist must choose between opening and closing the spaces linked to the absence of teeth, but however it is the clinical context that conditions the choice [11]. In our first clinical case, we opted for a space opening for the joint prosthesis. Faced with a morphological or digital disorder of the anterior teeth (agenetic upper lateral incisors), three more obvious therapeutic choices arise:

- Reopening of spaces and production of a conventional prosthesis (Bridges), replacing missing teeth

- Reopening of the unitary prosthesis space on implant

- Space closure and replacement of missing teeth by others [12].

Given the evolution of the implant technique, the optimal treatment of dental agenesis currently consists of the production of an implant-supported prosthesis [6] [13]. The implant treatment of dental agenesis represents a reliable esthetic solution and paradoxically less invasive than the traditional less economical bridge of dental tissues [10]. However, this multidisciplinary treatment presents a cost that is not always accessible for patients. This financial problem may force us to change our therapeutic strategy, None 
of our 2 patients being covered by a mutual or a social reimbursement system, the implant-supported prosthesis was abandoned by the first patient and the pre-prosthetic orthodontics was not done in the second. The objective of the treatment was the creation of prosthetic space on the one hand and the closure of the diastema in patient 1 , for patient 2 restore the line of occlusion and thus correct the dentoalveolar disorders (proalveoli, retroalveoli). Prosthetically, our two patients benefited from a bridge, one of which was of the cantilever type.

\section{Conclusion}

The main objective of managing agenesis is to correct the patient's dental aesthetics, but also to restore function while stimulating neuromuscular functions. This care comes at a cost because it is more often carried out in a multidisciplinary framework. The result generally obtained is satisfactory if the stages of the treatment are well respected. In our 2 cases our results were judged satisfactory by the patients.

\section{REFFERENCE}

1. Bassigny F. Manuel d'orthopédie dento-faciale.2ème éd. Paris: Masson; 1991-218.

2. De Coster PJ, Marks LA, Martens LC, Huysseune A. Dental agenesis: genetic and clinical perspectives. Journal of Oral Pathology \& Medicine. 2009 Jan;38(1):1-7.

3. Kennedy D. Orthodontic management of missing teeth. J Can Dent Assoc. 1999;65:548-550.

4. Muller T, Hill I, Peterson A, Blayney J. A survey of congenitally missing permanent teeth. J Am Dent Assoc. 1970;81:101-107.

5. Roy Sabri, Nadim Aboujaoude. Agénésie des incisives latérales maxillaires : approche orthodontique et implantaire Orthod Fr. 2008;79:283-293.

6. Noharet R. Traitement d'une agénésie dentaire antérieure chez l'adolescent. Problématiques et solution. les cahiers de prothèse. 2012 Mar(157):1.

7. Thierry M, Granat J, Vermelin L. Les agénésies dentaires: origine, évolution et orientations thérapeutiques. International orthodontics. 2007 Jun 1;5(2):163-82.

8. Barthelemi S, Jacquelin LF, Berthet A. Place de la canine dans le traitement des agénésies de l'incisive latérale maxillaire. RFOP Revue francophone d'odontologie pédiatrique. 2009;4(1):30-40.

9. Poulet H, Poulet C, Poulet C. Agénésies d'incisives: changer de paradigme. Étude d'une population orthodontique. Cas cliniques. Revue d'Orthopédie Dento-Faciale. 2014 Jul 1;48(3):26778.

10. Buatois H. Agénésie et traitement implantaire: l'importance de la préparation orthodontique. Revue d'Orthopédie Dento-Faciale. 2009 Mar 1;43(1):43-66.

11. Martin M. Possibilités thérapeutiques dans les cas d'agénésies d'incisives latérales supérieures. Revue d'Orthopédie Dento-Faciale. 1992 Mar 1;26(1):8797.

12. Jacques Faunes, Pascal Baron, Pierre Justumus. Agénésies des incisives latérales supérieures: Evaluation statistique des traitements par substitution. Revue d'orthopédie Dento-faciale. 28(2), 211-224, 1994.

13. Périsse J, Paoli JR, Lauwers F, Lupy G. Traitement d'un cas d'agénésies dentaires multiples: solution orthodontique et implantaire. Revue de stomatologie et de chirurgie maxillo-faciale. 1996;97(3):166-71. 